ISLAH: Journal of Islamic Literature and History

Vol. 1, No. 1, June 2020: p. 31-42. DOI: 10.18326/islah.v1i1.31-42

Website: https://e-journal.iainsalatiga.ac.id/index.php/islah

\title{
Ranggawarsita And Javanese Sufisme: A Study On Bagus Burham's Thought On Javanese Islam Culture (1823-1870)
}

\author{
Samudra Eka Cipta \\ Universitas Pendidikan Indonesia \\ samudraeka97@gmail.com
}

\begin{abstract}
The development of Javanese literature certainly cannot be separated from the role of poets who developed at the beginning of the 18th century. Most of their works were about social that described the dynamics of Javanese society at that time. Some of their works were about Islam, considering that at that time Islam became a feature of social identity for the Javanese people. Bagus Burham is one of the many poets born from the Kartasura palace. He was a poet as well as a man of letters and many of his works were about social and religious. His view about Islamic concept was presented by Ranggawarsita in Serat Wirid Hidayatjati \& Serat Kalatidha which discuss the concept of Islamisme Jawa according to his version. From the results of his thought then appeared a term for the Javanese Society called 'Islam Kejawen'. It is a concept that was first introduced by Ranggawarsita by integrating the concepts of Islam and Javanese. This is due to the fact that the emergence of poets was also in line with the emergence of the Javanese 'mystical' group. Ranggawarsita, through his works, seeks to accommodate the kebatinan group which was considered a heretical group and provides an opportunity for the group to understand and practice the teachings of Islam according to its version. So that the character of Ranggawarsita is highly respected by the community, especially the mystical groups.
\end{abstract}

Keywords: Kejawen, Ranggawarsita, Islam, Sufi, Java

\begin{abstract}
Abstrak
Perkembangan Kesusasteraan Jawa tentunya tidak terlepas dari peran para pujangga yang berkembang pada awal Abad ke-18 Masehi. Kebanyakan karya yang dihasilkan oleh para pujangga bertemakan tentang sosial. Isinya menggambarkan dinamika masyarakat Jawa saat itu. Tidak sedikit menghasilkan karya-karya yang bertemakan Islam, mengingat saat itu Islam menjadi suatu ciri identitas sosial masyarakat Jawa. Bagus Burham merupakan satu diantara banyak pujangga yang lahir dari kalangan Keraton Kartasura. Ia seorang pujangga sekaligus penyair dengan banyak karyanya yang bertemakan sosial dan agama. Karyanya tentang pandangan konsep Islam yang dikemukakan oleh Ranggawarsita dituangkan dalam Serat Wirid Hidayatjati \& Serat Kalatidha yang membahas tentang konsep "Islamisme Jawa" menurut versinya. Dari hasil pemikirannya kemudian berkembangnya suatu istilah bagi masyarakat Jawa yakni 'Islam Kejawen'. Islam Kejawen merupakan suatu konsep yang pertama kali diperkenalkan oleh Ranggawarsita dengan mempersatukan konsep ke-Islam dan kejawaan. Sebab, kemunculan para pujangga juga seiring dengan munculnya kelompok 'kebatinan' Jawa. Ranggawarsita melalui karyanya berusaha untuk mengakomodirkan kelompok kebatinan yang dianggap sebagai kelompok sesat dan memberikan kesempatan bagi kelompok tersebut untuk memahami dan mengamalkan ajaran Islam menurut versinya. Hal ini
\end{abstract}


menyebabkan ketokohan Ranggawarsita sangat dihormati bagi masyarakat khususnya kelompok kebatinan.

Kata Kunci: Kejawen, Ranggawarsita, Islam, Sufi, Jawa

\section{INTRODUCTION}

In the Javanese literary tradition, Bagus Burham is considered by the Javanese people as the last poet who has the ability to describe predictions as well as understanding about Islam through several of his works. A poet is the one with intelligence and memory who is able to understand the signs of social change that were previously unknown to many people. Ranggawarsita is also a social critic who turns his criticism into a literary work by refining the language.

The works of Bagus Burham marked the beginning of the revival of the Javanese literature development in the 19th century. In addition, it can be used as teaching materials in literary education in both schools and universities. While in college, his works become the source on historical development of Javanese literature.

\section{CONCEPTUAL FRAMEWORK}

In the discussion entitled "Ranggawarsita and Javanese Sufiism: Study of Good Burham's Thought of Javanese Islamic Culture" (1823-1870), there are several sub topics of discussion which consist of: 1) the religious conditions of Javanese society, 2) Javanese literary conditions, 3) Ranggawarsita biography, 4) Bagus Burham's work, 5) Bagus Burham's concept of Islam, and 6) elements of the historical philosophy of Bagus Burham's work .

The subject is then described in accordance with the facts discovered through the study of literature related to Bagus Burham. So it becomes a history regarding the role and understanding of Bagus Burham in interpreting Islam as a poet of the Keraton Surakarta.

\section{LITERATURE REVIEW}

\section{Multicultural}

The structure of Indonesian society is characterized by verbal and horizontal. Horizontally marked is by the existence of social units based on differences in ethnicity, religion, customs, and regional. Vertically, the structure of society is characterized by a caste layer in the social community. These differences are compounded which is a term to describe the condition of 
Indonesian society during the colonial period. The concept of plural society is a tropical community in which those in power and those the opposite has racial differences.

\section{Ethnography}

Ethnography is an embryo of anthropology appearing at the first stage of its development, which is before the year of 800. It is the record of European explorers when searching for spices in Indonesia. They noted all the interesting phenomena encountered during their journey, including its customs, society, language and physical characteristics of the ethnic groups.

Ethnography, as mentioned by Le Compte, et al. (t.t), is a qualitative research procedure to describe, analyze, and interpret elements of a cultural group such as patterns of behavior, beliefs, and language that develop over time. The focus of this research is culture. Culture itself is everything related to human behavior and beliefs. This includes language, ritual, economics, and political structure, life stages, interactions, and communication.

So it can be concluded that ethnographic research is a qualitative research examining life within a group or society scientifically that aims to study, describe, analyze, and interpret their cultural patterns in terms of behavior, beliefs, language, and shared views.

\section{Acculturation}

Acculturation is the process of integrating local culture with culture that comes from outside, then produces a new culture. Acculturation may have two effects. The first one is the beneficial and positive effect because the acculturation process can produce a new culture that is of high value, and has benefits.

Secondly, negative values occur in urban communities as quoted by Foster who illustrated that acculturation on urban society is eliminating traditional culture and the emergence of individualism patterns, and fostering hedonism behavior. ${ }^{1}$ However, this might not happen to all people when migrating to the city because there are some people who actually strengthen their cultural value even though they are migrating to cities.

\footnotetext{
${ }^{1}$ Foster. 1965. h. 45
} 


\section{METHODOLOGY}

\section{Data Collection}

The data is analyzed based on a literature study using a variety of literacy sources for this study, such as books, journals, and some internet sources that can be accounted for. This study used a qualitative approach which means that the result was written based on descriptive depictions from sources obtained as well as using historical methodology as the development of studies.

\section{Data Analysis}

The method used by the author is content study method using a literature study approach from various sources by examining a number of findings in the form of collecting books as a reference source as well as comparing the sources in this discussion. In addition, historical methods was also applied to see the development of historical learning in Indonesia by looking at historical events happened in the country. According to Helius Sjamsuddin, the historical method begins with the stages of data collection, criticism or verification, interpretation, and writing the history as a conceptual framework in a historical study. ${ }^{2}$

As mentioned by Klaus Kripendoff, the content analysis does not merely make the contents of the message as its object, but it also related to more recent conceptions of symbolic phenomena in the field of communication. Content analysis is a research technique for making inferences or statements that can be replicated and valid by paying attention to the context. ${ }^{3}$

\section{DISCUSSION}

\section{Religious Conditions of Javanese Community}

Islam became one of the religious centers as well as a cultural center by integrating religion with culture. Since the beginning of the Islamization process, the wali taught the magicalreligious element by using some intermediary media as a means for Islamization. Sunan Kalijaga teaches Islam by adjusting the needs and conditions of the local community. Religious became a symbol in the struggle for the king thrones which have been passed on since the Hindu-Buddhist period . Referring to the title given by the Islamic Mataram kings

\footnotetext{
${ }^{2}$ Helius Sjamsuddin. Metodologi Sejarah. (Yogyakarta: Penerbit Ombak, 2015). h. 30.

${ }^{3}$ Klaus Kripendoff. Analisis Isi: Pengantar Teori dan Metodologi. (Jakarta: Rajawali Press, Terjemahan, 1991).
} 
with Senapati-ing-Alaga Sayidin Panatagama Khalitafullah Ingkang Tanah Jawi who ordained himself as the leader of Javanese people.

The Kejawen school began as a concept of the emergence of tassawuf in Islam. Especially with regard to the nature of Makrifatullah which shows the human relations as God's creation interacting with God as the creator through various rituals and Islamic laws. The concept is rooted in a Javanese philosophy, in the expression of agama ageing aji and bisa ngaji, nanging aja dadi modin which means that religion is a guide, but does not make it a fanatic of his teachings. ${ }^{4}$

Aboebakar Atjeh explained that the essence of Tasawuf development is that it brings a spiritual level in establishing relationship between humans and his God. ${ }^{5}$ Tasawuf is one that limits the worldly desires within humans. It also teaches human to do ikhtiar for everything.

The teaching of suluk and primbon appeared during the development of Kejawen. The teachings should be initiated by the Javanese rural agrarian community. Because in its history, Javanese people really miss the power of euracakra (an understanding of the rise of Ratu Adil). So, the support of these teachings has emerged a new social movement known as Pamoring Kawula Gusti. Most of them accept the Islam as a complement to human life as the main foundation in learning and practicing the teachings of Tassawuf. Kejawen teachings have their own ways to get closer to their God, which of course, coincides with the emergence of various paguron or schools regarding physical, spiritual, and psychological matters.

According to Endaswara, the strength of the Javanese mysticism is the reunification of the human spirit with God, and rejuvenation of life. ${ }^{6}$ Javanese people see that God and humans do complement each other. The concept of Dzat is described as full power and is centralized. Javanese people's portrayal of God is always associated with sacred ceremonies to interact with God.

\section{Javanese Literature}

In the beginning of 19th century, the development of literature in Java was influenced by the dominance. Many epic literatures tell the devotion of the kings and the life of royal knight. Then the nature of the literature is istanasentris. Regarding the structural position given by the

\footnotetext{
${ }^{4}$ Mulyanto, dkk. Biografi Pujangga Ronggowarsito. (Jakarta: Departemen Pendidikan dan Kebudayaan. 1990). h. 27.

${ }^{5}$ Atjeh, A. Sedjarah Sufi Dan Tasawuf. (Bandung: Tjerdas. 1962). h. 15.

${ }^{6}$ Endaswara, S. Agama Jawa: Ajaran, Amalan, dan Asal Usul Kejawen. (Yogyakarta: Narasi, 2018). h. 
king, the poets were nominated as royal secretary assigned to maintain and wrote new books. The stories were written and aimed to have loyalty to the kingdom.

The values and elements of the literary work contain aesthetics in the use of diction and language. All stories tell about the praise of the king for his authority that was marked by his feudal, such as giving advice, discourses, wulang waruk, divination, hymns, and so on. On the other hand, there were also literatures telling about noble personality and being responsible to God or 'Sang Hayang Manon' in the philosophy of Javanese society. ${ }^{7}$

Literatures on socio-religious tells about all events as doomed by God. God as the narrator or dalang means the one who predestine something, while humans as the puppet are those who carry out the authority.

Literatures at that time underwent a process of modernization on the style and characteristic of language. The influence of the Dutch on the grammatical rules through political policy cannot be separated. For instance, the script that originally written in Javanese letters were then changed using Latin. The goal is the archives for the Netherlands.

\section{Biography of Ranggawarsita}

Raden Ngabehi Ronggowarsito, whose real name is Bagus Burhan, is the son of Raden Mas Pajangswara. Bagus Burhan is the grandson of Yosodipuro II, the main poet of Kasunanan Surakarta. From his family background, Bagus Burhan has nobleman blood in him. From his father, he has the blood of Sultan Pajang, Sultan Hadiwijaya; while from his mother side, he is a descendant from Raden Patah, Sultan of Demak Bintoro. ${ }^{8}$

Upon his return in Surakarta, Bagus Burhan was trained by his own grandfather, namely Raden Tumenggung Sastronegoro. He was also appointed by Panembahan Buminoto (Pakubuwana IV's younger brother) as Carik Kadipaten Anom with the title Mas Pajanganom on October 28, 1819. During the reign of Pakubuwana V (1820-1823), Burhan's career had faltered, because Pakubuwana V was not very fond of Panembahan Buminoto who always insisted on raising Bagus Burhan's rank.

During the period of Kartasura Kingdom, many Kejawen Mystical literary traditions emerged which were adapted from Persian Malay Literature. This tradition reached its prosperity during the era Kingdom of Surakarta with the development of high quality literature. The philosophy written by poets at that time sought to arouse people's enthusiasm

\footnotetext{
${ }^{7}$ Any, A. Raden Ngabehi Ronggowarsito Apa Yang Terjadi?. (Semarang: Aneka Ilmu. 1990). h. 35.

${ }^{8}$ Mulyanto, dkk. op.cit. h. 40.
} 
for the golden age of literature as in the Hindu-Buddhist era. The grandfather of Bagus Burham, Yosodipuro I and Yosodipuro II, became the pioneers in the improvement of literature, mainly in the use of language style.

On November 9, 1821 Bagus Burhan married Raden Ayu Gombak, daughter of Adipati Cakraningrat. He and his wife had moved along their in laws to Kediri before he finally decided to travel accompanied by Ki Tanujoyo. He travelled to Bali to learn from Kyai Tunggulwulung in Ngadiluwih, Kyai Ajar Wirakanta in Ragajambi, and Kyai Ajar Sidalaku in Tabanan Bali. On this precious occasion, he managed to bring home several journey notes and a number of kropak-kropak as well as old relics from Bali and Kediri to Surakarta.

Bagus Burham's art history can be traced further. From his mother's side, he was a descendant of Sujonopuro or better known as Prince Karanggayam, a poet from the Pajang Kingdom. He was a great man of letters and his famous book until today is Serat Niti Suri, a book about contains teachings about the ethics in life. Therefore, it was not a surprise if Bagus Burham was also interested in literature. Moreover, before the beginning of the XIX century is the peak of a genre in the history of Javanese literature known as the Islam Kejawen.

Bagus Burhan was appointed as Panewu Carik Duchy of Anom with the title of Raden Ngabei Ronggowarsito, replacing his late father who died in Dutch prison in 1830. After the death of Yasadipura II, Ranggawarsita was appointed as a poet of Kasunanan Surakarta by Pakubuwana VII on September 14, 1845.

\section{Ranggawarsita's Works on Javanese Literature}

On September 14, 1845 Bagus Burham was appointed to be a poet of Kasunanan Surakarta and was awarded the title 'Ngabehi'. Babad texts tend to be symbolic in describing the privilege about him. For example, he was told to understand the animal language. This was a symbol. Bagus Burham was very sensitive to people's lament. After his appointment, Bagus Burham wrote an essay entitled Fiber Jayeng Baya. It is a collection of his poems consisting of 250 verses of poetry telling a person in undergoing the process of searching for identity.

For the sake of the authorities at that time, Bagus Burham wrote two letters entitled Paramayoga and Pustaka Raja Purwa. Both letters were interrelated and tell about the history of the Prophet Adam which was associated with the Mythology of Javanese people to finally tell the lineage of kings. The king asked the poets to compile myths about their ancestors. This 
letter contains elements of historical philosophy, especially regarding the origin of the Javanese.

Bagus Burham also wrote Serat Cemporet which tells about three sons of the king who ran away from the palace and studied in a hermitage owned by Buyut Cemporet. The story tells a lot about the magic and greatness of the figures contained in the letter.

In second half of the 19th century, Bagus Burham's literary activities became more widespread. He then collaborated with the Dutch Colonial editor and magazine. That was when Jonas Portier (a Colonial daily magazine) published a Javanese-language magazine, called Bramartani. In addition, he also collaborated with Van der Vlis and C.F. Winter in writing a book Kawi-Javaansch Woordenboek. Their collaboration was then written in the form of agreement document. ${ }^{9}$

His career as a poet did not go smoothly, and he then wrote prophetic works. This happened when his relations with Pakubuwono VI were not in a good term. During his leadership, Bagus Burham always criticized the palace and the social conditions of the surrounding community. Bagus Burham wrote a Serat Kalatidha which tells about the chaos and hard times experienced by Kasunanan Surakarta. According to Musman, the word kalatidha comes from two words namely kala and tidha. Kala means era or period, while tidha means uncertain or vague or defective. It can be concluded that Kalatidha is literally a time of doubt. ${ }^{10}$

Bagus Burham called it as the Zaman Edan or the age of chaos showing the social changing in Javanese society and arbitrary actions carried out by the king, as well as the influence of Colonial culture which had taken root and entered the palace. The contents of Kalatidha were Bagus Burham's description of the social conditions surrounding Surakarta Palace. Many rulers did not set an example, many left the norm behind, and scholars always doubted the element of Javanese locality. Therefore, Bagus Burham did social criticism through the literary work.

\footnotetext{
${ }^{9}$ Norman, A. Zaman Edan Ronggowarsito. (Yogyakarta: Forum. 2013). h. 163.

${ }^{10}$ Musman, Pitutur Luhur Jawa: Ajaran Hidup dalam Serat Jawa. (Yogyakarta: Pustaka Jawi. 2017). h.
} 


\section{Burham's View On Islam}

Bagus Burham wrote a literary work entitled Serat Wirid Hidayat Jati. The work consists of his understanding of Islamic Fiqh according to Javanese culture. Ranggawarsita has divided seven categories on human nature, namely:

a. Hayyu means life, referred to atma (in Javanese terms), located outside of $d z a t$

b. Nur means light, called pranawa (in Javanese terms)

c. Sir means taste, called pramana (in Javanese terms)

d. Roh means soul, called suksma (in Javanese terms)

e. Nafsu means angkara (in Javanese terms)

f. Akal means budi (in Javanese terms)

g. Jasad means badan (in Javanese terms) ${ }^{11}$

The description above showed that the Essence of God is central point encircled by seven categories. All of them are inseparable. Those are the original manifestation of human nature as God's creatures. The naming of Wirid Hidayat Jati was the essence consist of moral message to all humans to always obey the command of God by carrying out the Shari'a or the provisions given by God.

The concept of Islam developed by Bagus Burham as written in Serat Wedhatama contains the concept of Makrifatullah with the assumption that the highest goal of life is the return to God as a determinant of the nature and destiny of human life. Mysticism as outlined in Serat Wedhatama is worship, creativity, soul, and taste. ${ }^{12}$ These four kinds of worship are sequentially the result of modifying the teachings of tasawuf.

The concept of Kawula Gusti teachings, which teaches about social harmony, was also introduced in this letter. The concept of Kawula Gusti is the concept of monotheism by describing God as a king, while humans which was described as God by carrying out orders from their kings, thus creating harmony and balance in human life.

Serat Wirid Hidayat Jati and Serat Wedhatama are strongly influenced by Islam by making the Qur'an as a reference in writing literary works written by Bagus Burham. The elements of syncretism of Hindu-Buddhist culture, Java, with Islam is clearly written in his works.

\footnotetext{
${ }^{11}$ Hariwijaya. Islam Kejawen. (Yogyakarta: Gelombang Pasang, 2014). h. 316.

${ }^{12}$ Simuh. Mistik Islam Kejawen Raden Ngabehi Ranggawarsita: Suatu Studi Terhadap Serat Wirid Hidayat Jati. (Jakarta: UI-Press, 1988). h. 252.
} 
The concept of human creation using the basic theory of martabat tujuh by Bagus Burham is the idea of Muhammad Ibn Fadlillah al-Burhanpuri in al-Tuhfah al-Mursalah ila Ruh al-Nabiy. The thinking of human creation as well as nature creation through the process of tajalli or God's emanation comes from the ideology of wujudiyah. Therefore, the basic theory in the martabat tujuh is also wujudiyah. Simuh has also confirmed that the basic teachings of tajalli originating from the ideology of martabat tujuh is from the adherents of Wahdat al-Wujud ideology. Thus, the teaching of martabat tujuh by Ronggowarsito was the same as wujudiyah.

Bagus Burham explained the concept of Manunggal Ing Kawula Gusti which is actually still very controversial because it is considered as making fool of the Islamic creed that sound:

'’Aku bersaksi kepada Dzat-Ku sendiri, bahwa sebenarnya tidak ada Tuhan selain Aku, dan bersaksi bahwa sebenarnya Muhammad itu utusan-Ku. Sebenarnya Allah itu BadanKu, Rasul rahsa-Ku, dan Muhammad cahaya-Ku', ${ }^{13}$

That is the concept of "nyawiji" which is a manifestation or wujud of faith itself. Faith means one or ahad or esa. The One God and there will be no other God. The One Tue God or Tuhan Yang Maha Esa and there is no other. He does not want to be doubted or cheated. This form must be upheld in all aspects of daily life. There is no word "bercabang" or splitting. It is a symbol of a snake's tongue, so the purpose will obviously be different. Nyawiji which also called as manunggal is the unity of two elements that become one. The concept of Manunggaling Kawula Lan Gusti does not mean humans become one with God. Humans are humans, and God is God. Manunggal means the union between physical and mental movements in worshiping God. When the vow is declared, takbirotul ikhram, then what is in the mouth, heart, hands, feet, eyes, and so on is only God.

At last, Bagus Burham wrote Serat Parmoling Gusti Kawula. This work tells about the process of dzikir as a form of worship. He did contemplation to God with a longing heart. Truly what is in nature emanates from God's will. Someone who read dzikir, said Bagus

${ }^{13}$ Mahmudi. Wirid Mistik Hidayat Jati: Mutiara Pemikiran Teologi Islam Kejawen. (Yogyakarta: Pura Pustaka, 2012). h. 105. 
Burham, is someone who expects ridho or the pleasure of God's authority as the creator of mankind. ${ }^{14}$

\section{HISTORICAL ELEMENTS IN BAGUS BURHAM PHLOSOPHY}

The works written by Bagus Burham are not only Islamic but also contained history in it. It is the prediction of history. Bagus Burham was able to predict the future by looking at phenomena which has similar symptoms to the past. ${ }^{15}$ His prediction ability was written in Serat Sabda Jati exactly eight days before his death on December 24, 1873. Some said that the death of Bagus Burham was due to Dutch interference, as his relationship with colonial officials and Paku Buwono VI was not very harmonious. So, many have assumed there was a dispute between the two to kill Bagus Burham.

The ability to predict was actually a must-have ability to every poet. Beside writing literary work, a poet should be able to answer various spiritual problems as well. It is sometimes used as an advisor to give policy for the palace. Bagus Burham was also capable to capture natural phenomena that are not necessarily possessed by everyone.

\section{CONCLUSION}

Bagus Burham or Ronggowarsito played an important role in the Javanese literature through his thoughts on Islamic matters. Bagus Burham is considered as a person with noble values and character in preserving Javanese customs and culture.

As a santri, he was able to write various literatures on worship procedures that were modified into the tradition of Javanese spiritualism. Ranggawarsita also mixed the element of klenik (something magical in nature) in his mysticism. This can be seen within his concept of human beings that humans who have experienced the union with God will become powerful so that it is the origin of nyawiji concept. What he said, will surely happen.

Therefore, it needs carefulness and vigilance in studying this teaching with a critical attitude. Thus, his books or literature is often used as the main reference in understanding the flow of Islam Kejawen. The mysticism school was widely spread in the era of 19th century.

\footnotetext{
${ }^{14}$ Karomi, K. (2020). Tuhan dalam Mistik Islam Kejawen (Kajian atas Pemikiran Raden Gabehi Ranggawarsita). [ONLINE]. Jurnal Kalimah Studi dan Pemikiran Islam. (Volume 11 No. 2, hlm. 35). Diakses 12 Februari, h. 292.

15 Widyanarko, D. (2004). Unsur-unsur Filsafat Sejarah Dalam Pemikiran R.N.G. Ranggawarsita. [ONLINE]. Jurnal Filsafat Universitas Gadjah Mada. (Volume 14 No. 1, h. 35). Diakses 13 Februari 2020.
} 


\section{REFERENCES}

Any, A. (1990). Raden Ngabehi Ronggowarsito Apa Yang Terjadi? Semarang: Aneka Ilmu.

Atjeh, A. (1962). Sedjarah Sufi Dan Tasawuf. Bandung: Tjerdas.

Cresswell, J. W. (2012). Eduactional Research: Planning, Conducting, and Evaluating Quantitative and Qualitative Research. New Jersey: Person Education, Inc.

Endraswara, S. (2018). Agama Jawa: Ajaran, Amalan, dan Asal Usul Kejawen. Yogyakarta: Narasi.

Handoyo, E. (2015). Studi Masyarakat Indonesia. Yogyakarta: Ombak.

Hariwijaya, M. (2014). Islam Kejawen. Yogyakarta: Gelombang Pasang.

Karomi, K. (2020). Tuhan dalam Mistik Islam Kejawen (Kajian atas Pemikiran Raden Ngabehi Ranggawarsita). Jurnal Kalimah Studi dan Pemikiran Islam, 11(2), 35.

Kripendoff, K. (1991). Analisis Isi: Pengantar Teori dan Metodologi (Terjemahan). Jakarta: Rajawali Pers.

Mahmudi. (2012). Wirid Mistik Hidayat Jati: Mutiara Pemikiran Teologi Islam Kejawen. Yogyakarta: Pura Pustaka.

Mulyanto, \& et.al. (1990). Biografi Pujangga Ronggowarsito. Jakarta: Departemen Pendidikan dan Kebudayaan.

Musman, A. (2017). Pitutur Luhur Jawa: Ajaran Hidup dalam Serat Jawa. Yogyakarta: Pustaka Jawi.

Norman, A. (2013). Zaman Edan Ronggowarsito. Yogyakarta: Forum.

Simuh. (1988). Mistik Islam Kejawen Raden Ngabehi Ranggawarsita: Suatu Studi Terhadap Serat Wirid Hidayat Jati. Jakarta: UI-Press.

Sjamsuddin, H. (2015). Metodologi Sejarah. Yogyakarta: Ombak.

Widyanarko, D. (2004). Unsur-unsur Filsafat Sejarah Dalam Pemikiran R.N.G. Ranggawarsita. Jurnal Filsafat Universitas Gadjah Mada, 14(1), 292. 